\title{
Activation of liver and muscle insulin receptor tyrosine kinase activity during in vivo insulin administration in rats
}

\author{
Y. T. Kruszynska, P. A. Halban, C. R. Kahn and M. F. White \\ Research Division, Joslin Diabetes Center, and Department of Medicine, Brigham and Women's Hospital, Boston, Massachusetts, USA
}

Summary. We have studied autophosphorylation and tyrosine kinase activity of the insulin receptor purified from liver and muscle of fasted rats before and after infusion of insulin $(100 \mathrm{mU} / \mathrm{h}$ ) during a $2.5 \mathrm{~h}$ glucose clamp. Recovery of insulin receptors and insulin binding to the solubilised receptors was unaffected by the glucose clamp. Autophosphorylation of the insulin receptor $\beta$ subunit was increased in liver receptors prepared from rats at the end of the glucose clamp compared to rats in the basal state both in the absence of insulin in vitro $(109 \%$ increase, $p<0.001)$ and after in vitro stimulation with $10^{-7} \mathrm{~mol} / 1$ insulin (clamped vs fasted; 96\% increase, $p<0.001)$. Insulin $\left(10^{-7} \mathrm{~mol} / \mathrm{l}\right)$ stimulated autophosphorylation was also increased in muscle receptor preparations from clamped rats compared with rats in the basal state $(58 \%$ increase, $p<0.05$ ). In both liver and muscle receptors, the clamp increased the amount of $\left[{ }^{32} \mathrm{P}\right]$-phosphate incorporated into the $\beta$ subunit without changing the sensitivity of the insulin stimulation. HPLC analysis of the tryptic phosphopeptides derived from the $\beta$ subunit after insulin stimulated autophosphorylation of liver receptors revealed an increase of ${ }^{32} \mathrm{P}$ in all phosphorylation sites without any change in the overall pattern. Tyrosine kinase activity of liver and muscle insulin receptors from clamped rats was also increased approximately twofold $(p<0.05)$ when analysed using a synthetic substrate (poly $\mathrm{Glu}_{4} \mathrm{Tyr}_{1}$ ). Our results support the notion that the insulin receptor exists in an active and inactive form, and that elevated plasma insulin concentrations increases the proportion of active receptors.

Key words: Hyperinsulinaemic glucose clamp, skeletal muscle, liver, insulin receptors, tyrosine kinase, insulin resistance, $\beta$-swbunit C-terminus.
The $\beta$ subunit of the insulin receptor is a tyrosine kinase $[1,2]$ which undergoes autophosphorylation immediately after the binding of insulin to the $\alpha$ subunit $[3,4]$. Site-directed mutagenesis of the $\beta$ subunit to alter the autophosphorylation cascade $[5,6]$, and introduction into intact cells of monoclonal antibodies which inhibit autophosphorylation [7], have revealed a close link between the tyrosine kinase activity of the receptor and insulin action. Thus, tyrosine kinase activity intrinsic to the insulin receptor may be important in some of the actions of insulin $[8,9]$.

The decrease in insulin receptor tyrosine kinase activity in adipocytes [10], liver [11] and skeletal muscle [12,13] from patients with Type 2 (non-insulin-dependent) diabetes may be important for the development of insulin resistance or even diabetes itself. However, it remains possible that the defect in tyrosine kinase activity in insulin target tissues is acquired as similar abnormalities can be induced by streptozotocin diabetes in rats $[14,15]$ and by dietary manipulation $[16,17]$. The biochemical mechanisms of these acquired defects are unknown but the hormonal milieu of the tissue prior to sampling could be important.
In contrast to the wealth of information on the regulation of the insulin receptor tyrosine kinase in purified insulin receptor preparations $[1-4,18-21]$ and in certain cultured cell lines [3-9,21-23] few studies have addressed the physiological regulation of the insulin receptor tyrosine kinase in the intact animal. This study examines in conscious rats the effects of a physiological increase in plasma insulin concentrations on the tyrosine kinase activity of insulin receptors in the two main insulin target tissues, liver and skeletal muscle. In order to provide a defined insulin stimulus without changes in blood glucose and counterregulatory hormone concentrations we have used the hyperinsulinaemic glucose clamp technique [24].

\section{Materials and methods}

\section{Animals}

Male Sprague Dawley rats (Charles River, Wilmington, Mass., USA) were maintained on laboratory chow ad libitum and weighed $300-350 \mathrm{~g}$ at the time of the study. Jugular and femoral venous cannulae were implanted under ether anaesthesia $24 \mathrm{~h}$ before the study. Following recovery from the anaesthetic rats were housed in individual cages with free access to water but not food. 


\section{Euglycaemic clamp studies}

On the morning of the study a basal blood sample $(200 \mu \mathrm{l})$ was taken for determination of blood glucose and plasma insulin concentrations. In six rats a $2.5 \mathrm{~h}$ infusion of neutral soluble insulin ( $\mathrm{Hu}-$ mulin R, Eli Lilly, Indianapolis, Ind., USA) diluted in Haemaccel (Hoechst, Frankfurt am Main, FRG) at a rate of $100 \mathrm{mU} / \mathrm{h}$ was started. This was infused through one limb of a double lumen cannula connected to the jugular venous cannula. Blood samples for glucose were taken at 5-10 min intervals from the femoral venous cannula and replaced with $0.15 \mathrm{~mol} / \mathrm{l}$ sodium chloride in water. Blood glucose concentration was measured by the glucose oxidase method (Yellow Springs Glucose Analyser, Clandon Scientific, Ohio, USA) within 2 min of obtaining the sample. Blood glucose was maintained at $4.0 \mathrm{mmol} / 1$ by a variable infusion of $500 \mathrm{~g} / 1$ glucose in water through the second limb of the double lumen cannula. Blood samples $(200 \mu \mathrm{l})$ for insulin were taken at 60,90 and $120 \mathrm{~min}$ and replaced with fresh washed rat erythrocytes in $0.15 \mathrm{~mol} / 1$ sodium chloride in water. A second group of six control rats was infused with Haemaccel alone for $2.5 \mathrm{~h}$. A similar schedule of blood sampling was used in these rats as in the insulin-infused rats. At the end of the study, control and glucose-clamped rats were anaesthetisted by i.v. injection of amylobarbitone $(0.02 \mathrm{~g}$ in $200 \mu 10.15 \mathrm{~mol} / \mathrm{l}$ sodium chloride in water) and liver and quadriceps muscle freeze-clamped, ground in liquid nitrogen and stored at $-70^{\circ} \mathrm{C}$ prior to solubilisation and purification of insulin receptors.

\section{Insulin receptor solubilisation}

Tissue $(-1 \mathrm{~g})$ was homogenised at $4^{\circ} \mathrm{C}$ (Polytron Kinematica, Lucerne, Switzerland) in $7 \mathrm{ml}$ of $50 \mathrm{mmol} / 1$ HEPES pH 7.4 containing $1 \%$ volume $/$ volume ( $/ \mathrm{v})$ Triton $\mathrm{X} 100,100 \mathrm{mmol} / \mathrm{l}$ sodium fluoride, $10 \mathrm{mmol} / \mathrm{l}$ sodium pyrophosphate, $2 \mathrm{mmol} / 1$ sodium vanadate, $5 \mathrm{mmol} / \mathrm{l} \mathrm{EDTA}, 2 \mathrm{mmol} / \mathrm{l}$ phenylmethylsulfonyl fluoride (PMSF) and $0.1 \mathrm{mg} / \mathrm{ml}$ aprotinin. The homogenate was stirred at $4{ }^{\circ} \mathrm{C}$ for $1 \mathrm{~h}$ and detergent insoluble material sedimented by centrifugation at $50,000 \mathrm{rev} / \mathrm{min}$ in a Beckman $70.1 \mathrm{Ti}$ rotor for $60 \mathrm{~min}$ at $4^{\circ} \mathrm{C}$. The supernatant was passed four times over an agarose bound wheat germ agglutinin (WGA) column (Vector Laboratories, Burlingame, Calif., USA). The resin was washed with $200 \mathrm{ml}$ ( 80 bed volumes) of $50 \mathrm{mmol} / 1 \mathrm{HEPES}$ pH 7.4 containing $0.1 \%$ Triton X100, $100 \mathrm{mmol} / \mathrm{l}$ sodium fluoride, $5 \mathrm{mmol} / \mathrm{l}$ EDTA, $10 \mathrm{mmol} / \mathrm{l}$ sodium pyrophosphate and $2 \mathrm{mmol} / \mathrm{l}$ sodium vanadate. Immediately before elution, the agarose was washed with $20 \mathrm{ml} 50 \mathrm{mmol} / \mathrm{l}$ HEPES $\mathrm{pH} 7.4$ containing $0.1 \% \mathrm{v} / \mathrm{v}$ Triton X100 and $4 \mathrm{mmol} / 1$ EDTA. The glycoproteins were eluted with $5 \mathrm{ml}$ of this solution containing $300 \mathrm{mmol} / \mathrm{l} \mathrm{N}$-acetylglucosamine (Sigma, St Louis, Mo., USA). Eluates were divided into $100-200 \mu \mathrm{l}$ aliquots and stored at $-70^{\circ} \mathrm{C}$. The protein concentration was determined using the Bio Rad protein assay [25].

\section{Binding of ${ }^{125} I$-insulin to solubilised insulin receptors}

Aliquots of WGA eluate were incubated at $4^{\circ} \mathrm{C}$ for $16 \mathrm{~h}$ with $\mathrm{A14}$ ${ }^{125} \mathrm{I}$-insulin (specific activity, $2000 \mathrm{Ci} / \mathrm{mmol}$ ), and a range of concentrations of unlabelled human insulin (Eli Lilly) in $200 \mu \mathrm{l}$ of $50 \mathrm{mmol} / \mathrm{l}$ HEPES buffer pH 7.4 containing $0.1 \%$ (v/v) Triton X100, $150 \mathrm{mmol} / \mathrm{l}$ sodium chloride and $1 \mathrm{~g} / \mathrm{l}$ bovine serum albumin. Insulin receptor complexes were precipitated in the presence of $1 \mathrm{~g} / \mathrm{l}$ human gamma globulin with $125 \mathrm{~g} / \mathrm{l}$ polyethylene glycol (final concentration) at $4^{\circ} \mathrm{C}[26]$. Insulin binding was corrected for non-specific binding determined in the presence of $10^{-5} \mathrm{~mol} / 1$ insulin. In all experiments comparing tissue from clamped and control rats equal binding activity was used in the assays.

\section{Receptor autophosphorylation}

WGA-purified insulin receptor from liver $(5 \mu \mathrm{g}$ protein) and muscle $\left(10 \mu \mathrm{g}\right.$. protein) were incubated at $22^{\circ} \mathrm{C}$ for $30 \mathrm{~min}$ in $45 \mu \mathrm{l}$ of
$10 \mathrm{mmol} / \mathrm{l}$ HEPES $\mathrm{pH} 7.4$ containing $10 \mathrm{mmol} / \mathrm{l}$ manganese chloride, $150 \mathrm{mmol} / \mathrm{l}$ sodium chloride, $1 \mathrm{~g} / \mathrm{l}$ bovine serum albumin in the absence or presence of insulin concentrations ranging from $3 \times 10^{-10}$ to $1 \times 10^{-7} \mathrm{~mol} / \mathrm{l}$. Phosphorylation was initiated by adding $60 \mu \mathrm{Ci} \gamma-{ }^{32} \mathrm{P}$-ATP to give a final ATP concentration in the assay of $25 \mu \mathrm{mol} / \mathrm{l}$. The phosphorylation reaction was terminated by adding $500 \mu \mathrm{l}$ of $50 \mathrm{mmol} / \mathrm{l} \mathrm{HEPES} \mathrm{pH} 7.4$ containing $0.1 \%$ (v/v) Triton $\mathrm{X} 100,100 \mathrm{mmol} / /$ sodium fluoride, $10 \mathrm{mmol} / \mathrm{l}$ sodium pyrophosphate, $5 \mathrm{mmol} / \mathrm{l}$ EDTA and $2 \mathrm{mmol} / \mathrm{l}$ sodium vanadate at $4^{\circ} \mathrm{C}$.

The phosphorylated insulin receptor was immunoprecipitated from each reaction with antiphosphotyrosine antibody prepared as previously described [27]. Purified IgG $(3 \mu \mathrm{g})$ was added to the phosphorylated insulin receptor preparations and incubated at $4^{\circ} \mathrm{C}$ for $16 \mathrm{~h}$. The antibody was immobilised on Pansorbin $(10 \% \mathrm{v} / \mathrm{v}, 100 \mu \mathrm{l})$ and the precipitate washed sequentially with $50 \mathrm{mmol} / \mathrm{l}$ HEPES pH 7.4 containing $1 \%(\mathrm{v} / \mathrm{v})$ Triton X100 and $1 \mathrm{~g} / \mathrm{l}$ sodium dodecyl sulfate (SDS) and then with $50 \mathrm{mmol} / \mathrm{l}$ HEPES pH 7.4 containing $0.1 \%(\mathrm{v} / \mathrm{v})$ Triton X100 and $1 \mathrm{~g} / \mathrm{l} \mathrm{SDS}$. The phosphoproteins were eluted from the Pansorbin with Laemmli sample buffer containing $100 \mathrm{mmol} / \mathrm{l}$ dithiothreitol, separated by SDS-polyacrylamide gel electrophoresis (PAGE) using 7.5\% resolving gels, and identified by autoradiography of Coomassie blue-stained, dried gels at $-70^{\circ} \mathrm{C}$ with Kodak x-Omat AR film using a Cronex lightning plus enhancing screen. Radioactivity in gel fragments was measured by Cerenkov counting.

\section{HPLC separation of tryptic phosphopeptides}

The phosphorylated insulin receptor $\beta$ subunit resolved by PAGE was digested with TPCK (N-tosylphenylalanyl chloromethyl ketone)-treated trypsin (Worthington Biochem Corp, Freehold, New Jersey, USA) and the phosphopeptides eluted from gel fragments as previously described [28]. The phosphopeptides which eluted from the gel fragment (about $80 \%$ ) were separated with a Waters HPLC system equipped with a widepore $\mathrm{C} 18$ reverse-phase column (RP318, Bio-Rad, Richmond, Calif., USA). The phosphopeptides were applied to the column in $0.05 \%(\mathrm{v} / \mathrm{v})$ trifluoroacetic acid and the column was eluted by a gradient of acetonitrile increasing linearly from $5 \%$ to $25 \%$ over $80 \mathrm{~min}$. Fractions $(1 \mathrm{ml})$ were collected at $1 \mathrm{~min}$ intervals and the radioactivity measured with $40 \%$ efficiency as Cerenkov radiation using a Beckman scintillation counter. Greater than $95 \%$ of the radioactivity in the trypsin digest was routinely recovered from the reverse phase HPLC column.

\section{Tryptic removal of the $\beta$-subunit $C$-terminus}

To examine the influence of the C-terminal domain of the insulin receptor $\beta$ subunit on the tyrosine kinase activities of receptors from fasted and clamped rats, autophosphorylation was also measured after removal of this domain by mild tryptic digestion as previously described [28]. Briefly, wheat germ purified receptor preparations were incubated with TPCK-treated trypsin $(5 \mu \mathrm{g} / \mathrm{ml})$ for $1 \mathrm{~min}$ at $22^{\circ} \mathrm{C}$ and digestion stopped by the addition of aprotinin to a final concentration of $10 \mu \mathrm{g} / \mathrm{ml}$. Autophosphorylation was then measured as described above.

\section{Phosphorylation of an exogenous substrate}

WGA-purified receptor preparations $(5-10 \mu \mathrm{g}$ protein) were preincubated for $30 \mathrm{~min}$ at $22^{\circ} \mathrm{C}$ in $10 \mathrm{mmol} / / \mathrm{HEPES}$ pH 7.4 containing $0.05 \mathrm{mmol} / 1 \mathrm{ATP}, 5 \mathrm{mmol} / \mathrm{l}$ manganese chloride, $10 \mathrm{mmol} / \mathrm{l} \mathrm{magne-}$ sium acetate and $10^{-7} \mathrm{~mol} / \mathrm{l}$ insulin. The reaction (final volume $50 \mu \mathrm{l}$ ) was initiated by the addition of substrate (copolymer of Glu/Tyr, 4:1, $1 \mathrm{mg} / \mathrm{ml}$, Sigma) and $3 \mu \mathrm{Ci}$ of $\gamma^{-32}$ P-ATP. After $15 \mathrm{~min}$ the reaction was stopped by adding $20 \mu \mathrm{l}$ of $40 \mathrm{mmol} / \mathrm{l}$ HEPES $\mathrm{pH} 7.4$ containing $20 \mathrm{mmol} / 1 \mathrm{EDTA}, 200 \mathrm{mmol} / \mathrm{l}$ sodium fluoride, $40 \mathrm{mmol} / \mathrm{l}$ sodium pyrophosphate, $40 \mathrm{mmol} / \mathrm{l}$ sodium phosphate, $40 \mathrm{mmol} / \mathrm{ATP}$ and $0.4 \%$ (v/v) Triton X100. Aliquots were then ap- 
plied to filter paper squares and washed in $100 \mathrm{~g} / 1$ trichloroacetic acid containing $1 \mathrm{mmol} / \mathrm{l}$ sodium pyrophosphate. Papers were washed five times over $6 \mathrm{~h}$, dried and counted using Cerenkov counting. Non-specific binding of $\gamma^{32} \mathrm{P}$-ATP to the papers (measured in the absence of poly $\mathrm{Glu}_{4} \mathrm{Tyr}_{1}$ ) accounted for $2-8 \%$ of radioactivity bound and was subtracted from measured values to give specific binding. All assays were performed in duplicate.

\section{Other analyses}

Plasma insulin was measured by RIA [29] using a human or rat standard as appropriate.

\section{Statistical analysis}

Results are presented as mean \pm SEM. Significant differences between the groups were assessed by Student's paired or unpaired $t$-test as appropriate.

\section{Results}

\section{Blood glucose and plasma insulin concentrations}

Blood glucose concentrations in $24 \mathrm{~h}$ fasted rats before the glucose clamp were $3.8 \pm 0.2 \mathrm{mmol} / \mathrm{l}$. This was associated with a fasting plasma insulin concentration of $1.09 \pm 0.12 \mu \mathrm{g} / \mathrm{l}$. During the last $30 \mathrm{~min}$ of the $2.5 \mathrm{~h}$ clamp, blood glucose concentration was $4.0 \pm 0.0$ (SD) $\mathrm{mmol} / \mathrm{l}$. The coefficient of variation of blood glucose for this period measured for each animal was $2.5 \pm 1.0$ (SD)\%. Steady state plasma insulin concentrations measured over the last $60 \mathrm{~min}$ of the clamp were $142 \pm 9 \mathrm{mU} / 1(0.85 \pm 0.05 \mathrm{nmol} / \mathrm{l}$, human assay). The glucose infusion rate required to maintain the clamp calculated for the period +120 to $150 \mathrm{~min}$ was $168 \pm 8 \mu \mathrm{mol} \cdot \mathrm{min}^{-1} \cdot \mathrm{kg}^{-1}$.

\section{Insulin binding}

Recoveries of WGA-purified glycoprotein (liver: - basal, $4.23 \pm 0.27$, clamp, $4.58 \pm 0.22 \mathrm{mg} / \mathrm{g}$; muscle: - basal,

Table 1. Effect of removal of the $\beta$ subunit C-terminus on in vitro autophosphorylation of liver and skeletal muscle insulin receptors prepared from rats after a $24 \mathrm{~h}$ fast and at the end of a hyperinsulinaemic glucose clamp

\begin{tabular}{|c|c|c|c|}
\hline & \multirow{2}{*}{$\begin{array}{l}\text { In vitro } \\
\text { insulin } \\
\left(10^{-7} \mathrm{~mol} / \mathrm{l}\right)\end{array}$} & \multicolumn{2}{|c|}{$\beta$ subunit ${ }^{32} \mathrm{P}$ incorporation (cpm) } \\
\hline & & Intact receptors & $\begin{array}{l}\text { Truncated recep- } \\
\text { tors }\end{array}$ \\
\hline \multicolumn{4}{|l|}{ Liver } \\
\hline Fasting & $\begin{array}{l}- \\
+\end{array}$ & $\begin{array}{r}728 \pm 98 \\
5661 \pm 340\end{array}$ & $\begin{array}{r}155 \pm 39^{d} \\
4124 \pm 218^{c}\end{array}$ \\
\hline Clamp & $\begin{array}{l}- \\
+\end{array}$ & $\begin{array}{r}1578 \pm 146^{b} \\
12023 \pm 790^{b}\end{array}$ & $\begin{array}{c}373 \pm 159^{\mathrm{d}} \\
81.78 \pm 561^{\mathrm{b}, \mathrm{c}}\end{array}$ \\
\hline \multicolumn{4}{|l|}{ Muscle } \\
\hline Fasting & $\begin{array}{l}- \\
+\end{array}$ & $\begin{array}{r}47 \pm \quad 4 \\
1201 \pm 106\end{array}$ & $\begin{array}{cc}46 \pm & 5 \\
823 \pm & 79^{d}\end{array}$ \\
\hline Clamp & $\begin{array}{l}- \\
+\end{array}$ & $\begin{array}{c}56 \pm \quad 7 \\
2202 \pm 294^{\text {a }}\end{array}$ & $\begin{array}{c}47 \pm \quad 5 \\
1442 \pm 166^{\mathrm{a}, \mathrm{c}}\end{array}$ \\
\hline
\end{tabular}

Mean $\pm \operatorname{SEM}\left(n=6\right.$ in each group) ${ }^{\mathrm{a}, \mathrm{b}} p<0.01, p<0.001$ compared with receptors from fasted rats. ${ }^{c . d} p<0.01, p<0.001$ compared with receptors with an intact $\beta$ subunit

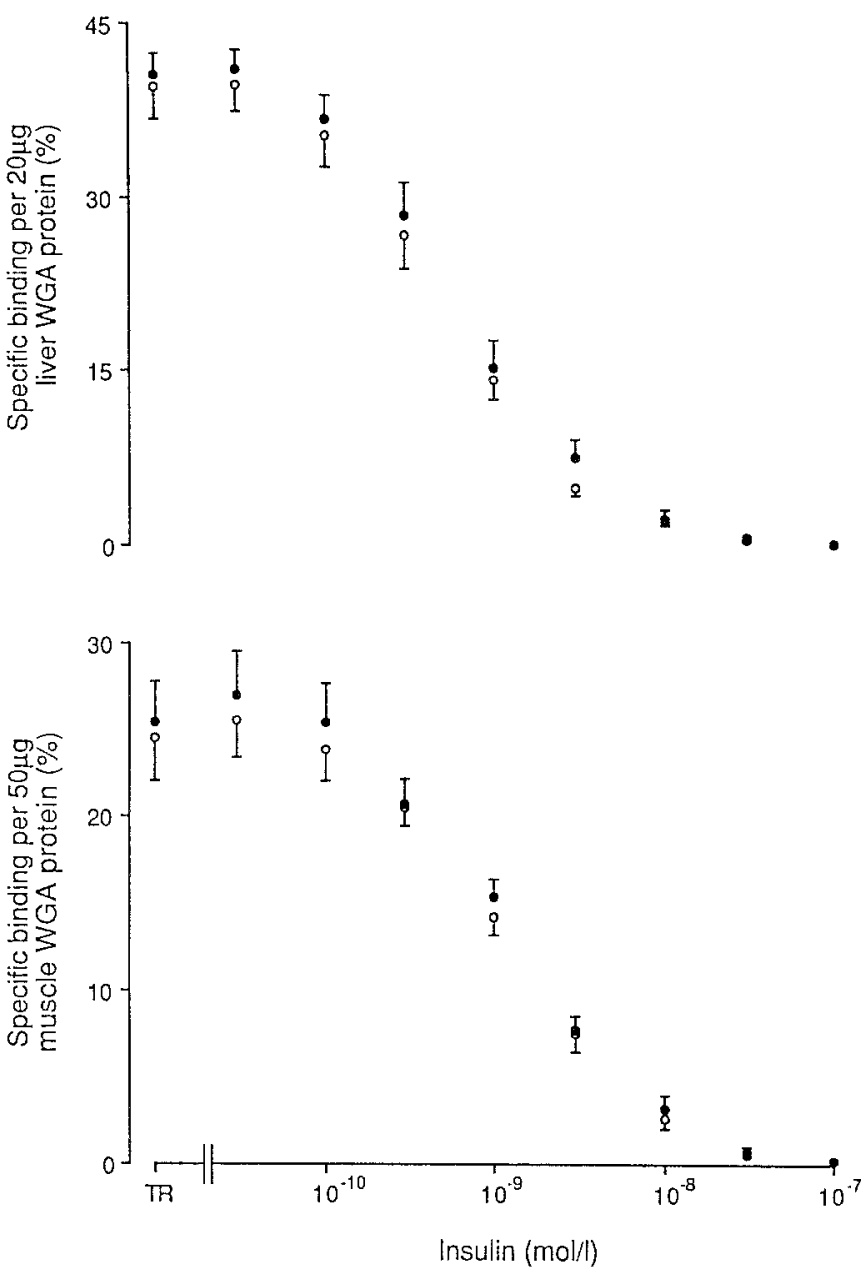

Fig. 1. Specific insulin binding to liver (top) and muscle (bottom) partially purified insulin receptors prepared from rats fasted for $24 \mathrm{~h}$

( ) and at the end of a hyperinsulinaemic glucose clamp (O). $n=6$ in each group. The wheat germ agglutinin (WGA) eluate (muscle, $50 \mu \mathrm{g}$ protein; liver, $20 \mu \mathrm{g}$ protein) was incubated with $\mathrm{A}-14{ }^{-125} \mathrm{I}$-insulin $(\sim 15000 \mathrm{cpm})$ in $200 \mu \mathrm{l}$ buffer in the absence (TR) or presence of unlabelled insulin in increasing concentrations. Hormone receptor complexes were precipitated with polyethylene glycol. Non-specific binding obtained in the presence of $10^{-5} \mathrm{~mol} / \mathrm{l}$ insulin was subtracted from total binding

$1.71 \pm 0.25$, clamp $1.72 \pm 0.15 \mathrm{mg} / \mathrm{g}$ ) and of WGA-purified insulin receptors (liver: - basal, $71 \pm 4$, clamp $67 \pm 3 \%$; muscle: - basal, $71 \pm 3$, clamp $69 \pm 3 \%$ ) were not affected by the glucose clamp. Equilibrium binding of ${ }^{125} \mathrm{I}$-insulin to partially purified insulin receptors extracted from liver and quadriceps skeletal muscle was identical in basal and clamped rats (Fig.1). Apparent affinity of receptors for insulin was estimated from the insulin concentrations necessary for half maximal displacement of tracer. This was not affected by the glucose clamp in either skeletal muscle (fasted, $1.29 \pm 0.12 \mathrm{nmol} / \mathrm{l}$, clamp, $1.33 \pm 0.15$ $\mathrm{nmol} / \mathrm{l}$ ) or liver insulin receptor preparations (fasted, $0.75 \pm 0.15$, clamp, $0.56 \pm 0.06 \mathrm{nmol} / 1$ ) (Fig. 1).

\section{Insulin stimulated autophosphorylation}

Insulin stimulated tyrosyl phosphorylation of a 95 kilodalton $(\mathrm{kD})$ protein in WGA-purified extracts from rat liver 


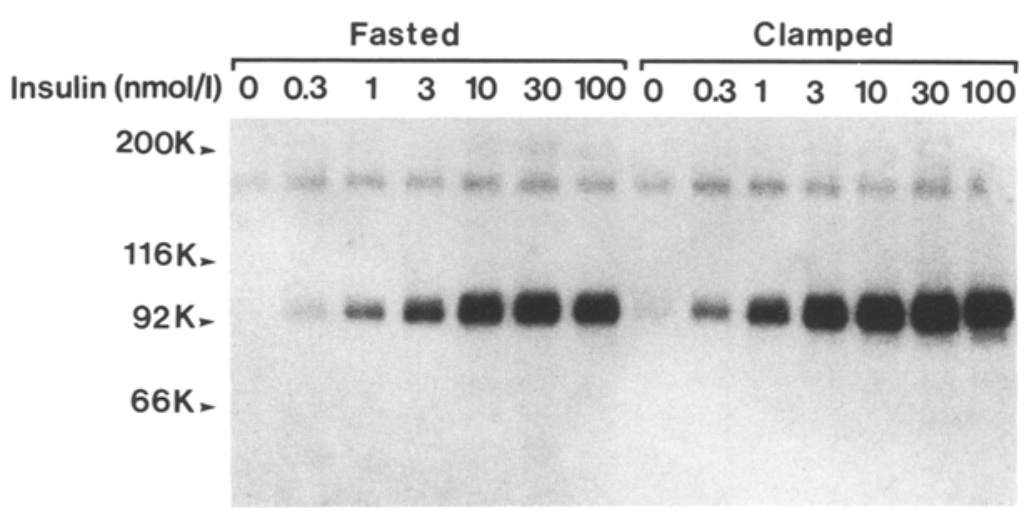

Fig. 2. Insulin dose dependence of autophosphorylation of insulin receptors partially purified from skeletal muscle of a rat fasted for $24 \mathrm{~h}$ and a rat at the end of a hyperinsulinaemic glucose clamp. Muscle wheat germ agglutinin-purified insulin receptors $(10 \mu \mathrm{g}$ protein) were incubated at $22^{\circ} \mathrm{C}$ for $30 \mathrm{~min}$ in the absence or presence of increasing insulin concentrations. Phosphorylation was initiated by adding $\gamma_{-}^{32}$ P-ATP $(25 \mu \mathrm{mol} / \mathrm{l})$ and after $10 \mathrm{~min}$ at $22^{\circ} \mathrm{C}$ the phosphorylated receptors were immunoprecipitated with antiphosphotyrosine antibody at $4^{\circ} \mathrm{C}$. Phosphoproteins were separated by sodium dodecyl sulfatepolyacrylamide gel electrophoresis and subjected to autoradiography. $\mathrm{K}=$ Kilodalton

and skeletal muscle. Based on its $\mathrm{M}_{\mathrm{r}}$ and immunoreactivity with antibody [28] directed against the C-terminus of the insulin receptor $\beta$-subunit this phosphoprotein is the $\beta$ subunit of the insulin receptor. Steady state phosphorylation of the $\beta$ subunit was attained by 5 min of incubation with $\gamma^{32} \mathrm{P}$-ATP $(25 \mu \mathrm{mol} / \mathrm{l})$, manganese chloride $(5 \mu \mathrm{mol} / \mathrm{l})$ and insulin at $22^{\circ} \mathrm{C}$ (data not shown). Increasing concentrations of insulin resulted in a dose-dependent stimulation of phosphorylation of the $\beta$ subunit (Fig. 2).

Intravenous infusion of insulin for $2.5 \mathrm{~h}$ in $24 \mathrm{~h}$ fasted rats, with maintenance of blood glucose at $4.0 \mathrm{mmol} / \mathrm{l}$, resulted in an activation of the insulin receptor in both liver and skeletal muscle (Fig. 3). Thus, in wheat germ purified liver or muscle receptors from clamped rats, autophosphorylation of the $\beta$ subunit was increased approximately twofold and 1.5-fold, respectively compared to receptors prepared from rats in the basal state. In both liver and muscle this stimulation was observed over the whole range of insulin concentrations tested (Fig.3). In liver, stimulation was also seen in the absence of insulin in vitro (Fig. 3).

\section{Peptide mapping of the $\beta$-subunit of the insulin receptor}

To assess whether the stimulation of insulin receptor autophosphorylation by hyperinsulinaemia was associated with qualitative differences in the sites of phosphate incorporation into the $\beta$ subunit during the in vitro assay, the HPLC profiles of tryptic phosphopeptides obtained from the autophosphorylated $\beta$ subunits from basal and clamped rats were compared. In receptor preparations from both basal and clamped rats, 6 phosphopeptide peaks were resolved (Fig. 4) which have previously been shown to contain phosphotyrosine [18]. Peaks PY1 and PY1a represent triphosphorylated forms of the regulatory domain containing $\operatorname{Tyr}(\mathrm{P}) 1146, \operatorname{Tyr}(\mathrm{P}) 1150$ and $\operatorname{Tyr}(\mathrm{P}) 1151[18,19]$. Peaks PY2 and PY3 are derived from the $\mathrm{C}$-terminus of the $\beta$-subunit and contain $\operatorname{Tyr}(\mathrm{P}) 1316$ and $\operatorname{Tyr}(\mathrm{P}) 1322[18,19]$. Peaks designated PY4 and PY5 are thought to represent diphosphorylated forms of the regulatory region [18], containing $\operatorname{Tyr}(\mathrm{P}) 1146$ and either $\operatorname{Tyr}(\mathrm{P}) 1150$ or $\operatorname{Tyr}(\mathrm{P})$ 1151. The glucose clamp increased the amount of radioactivity associated with each of these peaks without any consistent change in the overall pattern (Fig.4). Due to low specific activity, it was not possible to obtain comparable profiles of tryptic phosphopeptides from muscle insulin receptors in this study.
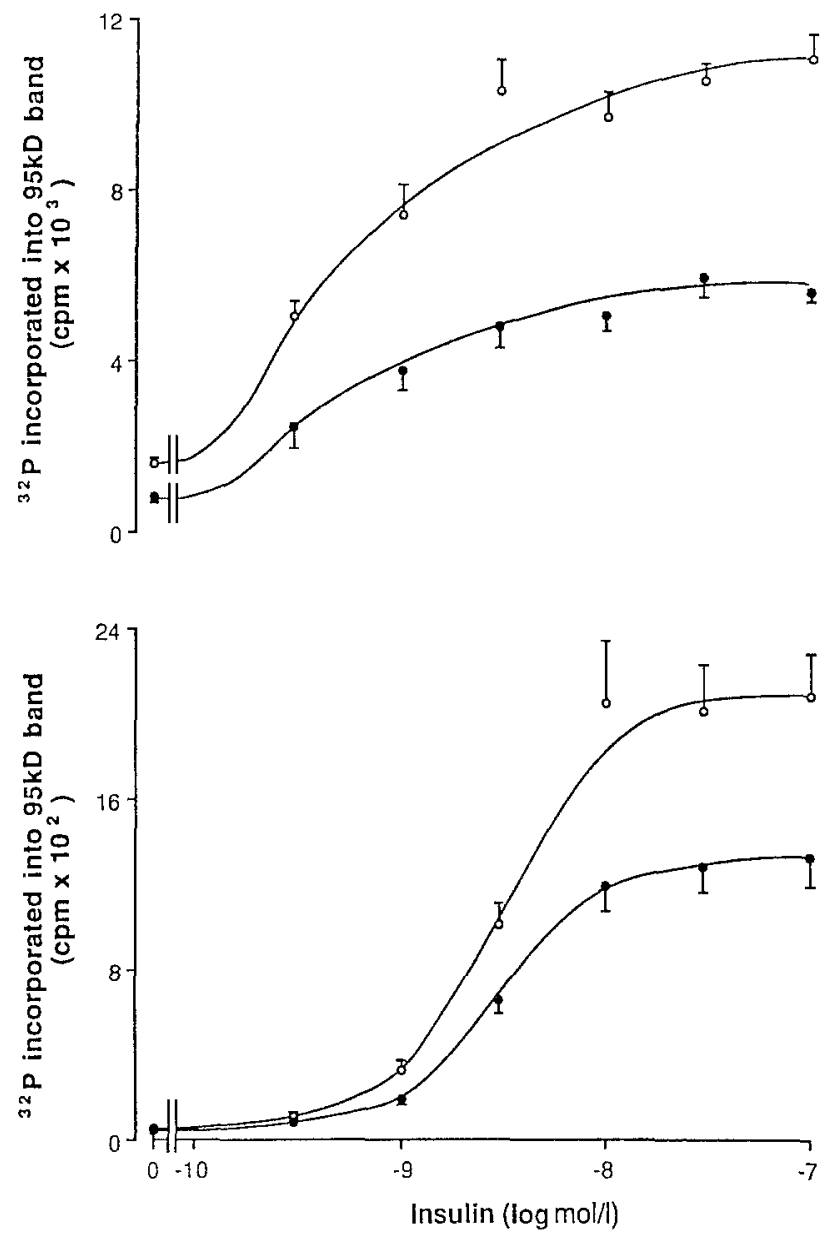

Fig. 3. In vitro autophosphorylation of wheat germ agglutinin (WGA)-purified insulin receptors from liver (top) and muscle (bottom). Receptors were prepared from rats fasted for $24 \mathrm{~h}(\bullet)$ and from rats at the end of a hyperinsulinaemic glucose clamp (O). WGA-purified receptors from liver ( $5 \mu \mathrm{g}$ protein $)$ and muscle $(10 \mu \mathrm{g}$ protein) were incubated with $\gamma^{32} \mathrm{P}$-ATP and varying insulin concentrations at $22^{\circ} \mathrm{C}$ as described in Figure 2. Phosphorylated receptors were immunoprecipated with antiphosphotyrosine antibody, separated by sodium dodecyl sulfate-polyacrylamide gel electrophoresis and subjected to autoradiography. ${ }^{32} \mathrm{P}$ incorporation in to the 95 Kilodalton (kD) subunit of the insulin receptor was determined by Cerenkov counting of excised gel bands. $n=6$ in each group 


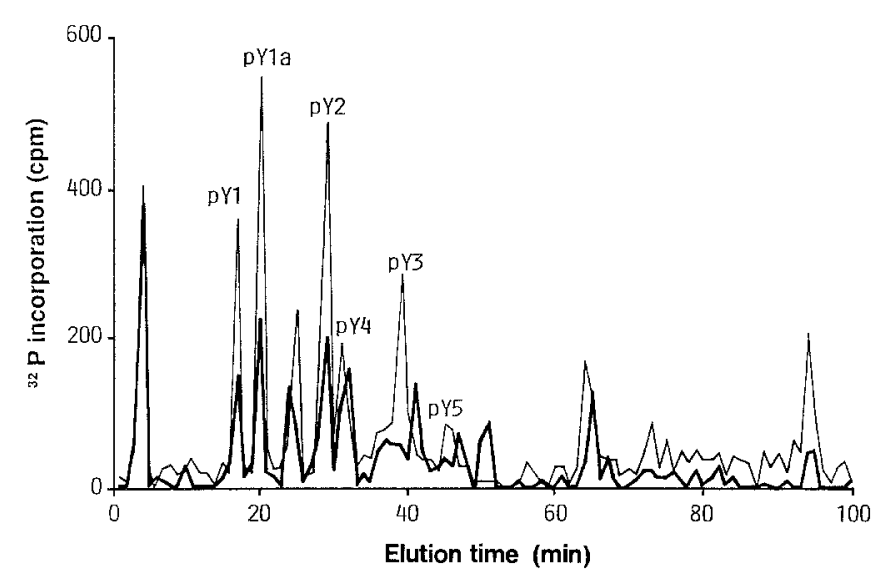

Fig. 4. Reverse phase HPLC profiles of liver insulin receptor $\beta$ subunit tryptic phosphopeptides after in vitro autophosphorylation for $10 \mathrm{~min}$ at $22^{\circ} \mathrm{C}$ in the presence of $100 \mathrm{nmol} / 1$ insulin. For experimental details see legend to Figure 2 . The thick line represents the profile for a single fasted rat, the fine line is derived from a clamped rat. Peaks pY1 and pY1a: triphosphorylated peptides containing Tyr (P) 1146, Tyr (P) 1150, Tyr (P) 1151; peaks pY2 and pY3: derived from the C-terminus and contain Tyr $(\mathrm{P}) 1316$ and Tyr (P) 1322; peaks pY4 and pY5: diphosphorylated peptides containing Tyr (P) 1146 and Tyr (P) 1150 or Tyr (P) 1151
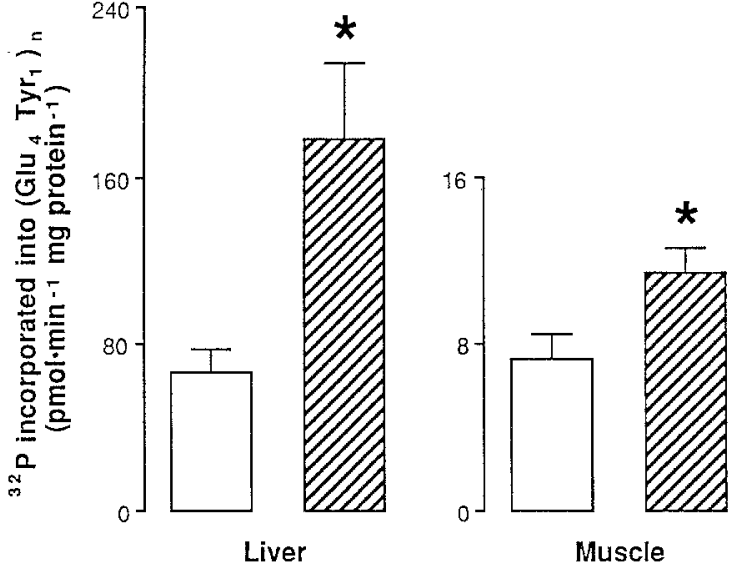

Fig. 6. Tyrosine kinase activity of insulin receptors from liver and skeletal muscle towards an exogenous substrate (poly $\mathrm{Glu}_{4} \mathrm{Tyr}_{1}$ ). Receptors were prepared from rats fasted for $24 \mathrm{~h}(\square)$ and from rats at the end of a hyperinsulinaemic glucose clamp (W). Wheat germagglutinin-purified receptors (liver, $5 \mu \mathrm{g}$ protein; muscle, $10 \mu \mathrm{g}$ protein) were preincubated for $30 \mathrm{~min}$ at $22^{\circ} \mathrm{C}$ with $50 \mu \mathrm{mol} / 1 \mathrm{ATP}$ and $100 \mathrm{nmol} / 1$ insulin. The reaction was initiated by adding $3 \mu \mathrm{Ci} \gamma^{32} \mathrm{P}$ ATP and poly $\mathrm{Glu}_{4} \mathrm{Tyr}_{1}$ (final concentration $1 \mathrm{mg} / \mathrm{ml}$ ). After $15 \mathrm{~min}$ the reaction was stopped as described in Materials and methods and incorporation into poly $\mathrm{Glu}_{4} \mathrm{Tyr}_{1}$, determined by Cerenkov counting. Mean \pm SEM, $n=6$ in each group. ${ }^{*} p<0.05$ compared with fasted rats

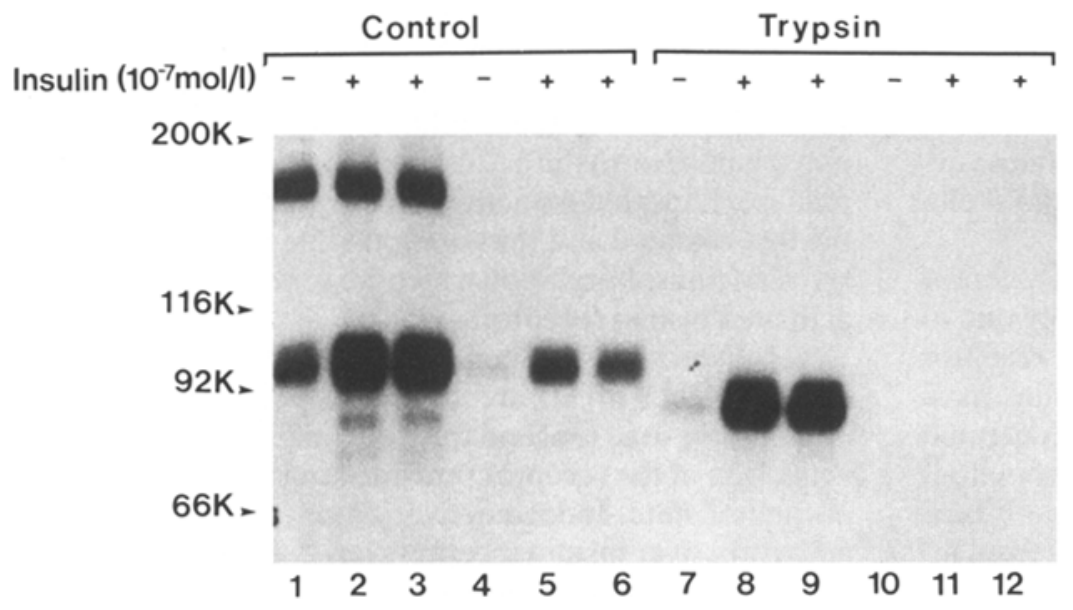

Fig.5. Autoradiogram showing the effect of mild trypsin digestion $(5 \mu \mathrm{g} / \mathrm{ml}, 1 \mathrm{~min})$ on the 95 kilodalton (K) $\beta$ subunit. Control and trypsin treated receptors were allowed to autophosphorylate $\left(10 \mathrm{~min}\right.$ at $\left.22^{\circ} \mathrm{C}\right)$ in the absence or presence of insulin $(100 \mathrm{nmol} / \mathrm{l})$. The autophosphorylated receptors were then immunoprecipitated with either antiphosphotyrosine antibody (lanes 1-3 and 7-9) or with antibody against the $C$-terminus of the $\beta$ subunit (lanes $4-6$ and 10-12). After reduction samples were subjected to sodium dodecyl sulfate-polyacrylamide gel electrophoresis and autoradiography as described in Materials and methods.

\section{Effect of removal of the $\beta$-subunit $C$-terminus}

Incubation of WGA-purified receptors for $1 \mathrm{~min}$ at $22^{\circ} \mathrm{C}$ with $5 \mu \mathrm{g} / \mathrm{ml}$ trypsin converted the $95 \mathrm{kD} \beta$ subunit to an $85 \mathrm{kD}$ fragment which was recognised by the antiphosphotyrosine antibody but not by the antibody directed against the $\mathrm{C}$ terminus (Fig. 5).

Incorporation of ${ }^{32} \mathrm{P}$ into liver $85 \mathrm{kD} \beta$ subunits measured in the absence of insulin in vitro was markedly decreased compared with native $\beta$ subunits (Table 1). This difference was also seen during insulin-stimulated autophosphorylation and was most likely due to removal of Cterminal autophosphorylation sites (Table 1). The 30\% decrease was, proportionate in preparations from basal and clamped rats. Thus, the difference in insulin stimulated receptor autophosphorylation between fasted and clamped rats was preserved despite removal of the $\beta$-subunit C-terminal region.
Incorporation of ${ }^{32} \mathrm{P}$ into muscle $95 \mathrm{kD} \beta$ subunits was very low when measured in the absence of insulin and it was not possible to demonstrate any effect of C-terminal removal on this low basal level of autophosphorylation. Removal of the $\beta$-subunit C-terminus from muscle receptors resulted in a similar decrease in insulin stimulated ${ }^{32} \mathrm{P}$ incorporation into the $85 \mathrm{kD}$ fragment to that seen in liver (Table 1). Removal of this domain did not change the differences between basal and clamped rats (Table 1).

\section{Phosphotransferase activity of the insulin receptor from basal and clamped rats}

To measure full activation of the phosphotransferase activity of the receptor, partially purified receptor preparations were allowed to reach a steady state level of autophosphorylation by preincubation for $30 \mathrm{~min}$ with insulin 
$\left(10^{-7} \mathrm{~mol} / \mathrm{l}\right)$ and unlabelled ATP prior to addition of the synthetic substrate and $\gamma^{32} \mathrm{P}$-ATP. Under these conditions ${ }^{32} \mathrm{P}$ incorporation into the copolymer of $\mathrm{Glu}_{4} \mathrm{Tyr}_{1}$ was linear for $20 \mathrm{~min}$ for both muscle and liver insulin receptor preparations. Both liver and skeletal muscle insulin receptor preparations from clamped rats showed increased phosphotransferase activity compared with receptors from rats in the basal state (Fig.6). Thus, the clamp increased the incorporation of ${ }^{32} \mathrm{P}$ into the copolymer $\mathrm{Glu}_{4} \mathrm{Tyr}_{1}$ by $166 \%$ in liver $(p<0.05)$ and by $56 \%$ in muscle $(p<0.05)$.

\section{Discussion}

Decreased insulin receptor tyrosine kinase activity observed in a number of insulin resistant states $[10-15,17$, 30] suggests an important role of the kinase in modulating insulin action and a mechanism for insulin resistance. However, insulin resistance, for example, in Type 2 diabetes and obesity is associated with abnormalities of insulin secretion which might be expected to result in alterated receptor kinase activity. Caution should thus be exercised in attributing tissue resistance to the decreased receptor kinase activity.

In this study we have investigated the effects on the tyrosine kinase of short-term exposure to a sustained elevation in plasma insulin concentrations as might be expected to occur in relation to meals. Infusion of insulin into $24 \mathrm{~h}$ fasted rats, without change in blood glucose concentration, increased autophosphorylation and kinase activity of the insulin receptor purified from liver and skeletal muscle.

It is unlikely that this activation of the insulin receptor tyrosine kinase during the glucose clamp is simply due to continued association of infused insulin with the receptor preparation. Previous studies using ${ }^{125} \mathrm{I}$-insulin have shown that negligible amounts of insulin can be detected following solubilisation and WGA agarose chromatography $[31,32]$. This is supported by the finding that ${ }^{125} \mathrm{I}$-insulin binding is identical in glycoprotein fractions from insulin infused and fasted rats. Furthermore, the persistence of the difference in tyrosine kinase activity in the in vitro assay between receptors from fasted and clamped rats at maximally stimulating insulin concentrations (approximately 100 -fold those attained in vivo) is inconsistent with the above hypothesis.

Enhanced autophosphorylation and tyrosine kinase activity in the in vitro assay in receptors from insulin infused rats cannot be explained by increased in vivo phosphorylation on tyrosines within the regulatory region of the $\beta$-subunit as less than $10 \%$ of the receptors are expected to be phosphorylated at $1 \mathrm{nmol} / 1$ insulin [22]. Moreover, any such increase would be manifest by an apparent decrease in autophosphorylation in the in vitro assay since some of the phosphorylation sites would be occupied by unlabelled phosphate.

In rat hepatocytes [33] and Fao hepatoma cells [34], a portion of occupied insulin receptors are phosphorylated not on tyrosine but on serine residues. These results suggest that phosphorylation of the insulin receptor on serine residues may regulate the tyrosyl kinase in vivo [35]. In our experiments, increased receptor autophosphorylation and kinase activity, and normal but elevated tryptic phosphopeptide maps suggest that the population of insulin receptors capable of autophosphorylation increased during in vivo exposure to elevated insulin concentrations. It is possible that the level of serine phosphorylation is enhanced during fasting but decreases following infusion of insulin with a concomitant increase in the proportion of receptors capable of autophosphorylation on tyrosine residues. Preliminary results suggest that a serine and threonine phosphorylation site may be located in the Cterminal region of the $\beta$ subunit raising the possibility that this domain exerts a regulatory role on the insulin receptor tyrosine kinase. However, autophosphorylation of liver and skeletal muscle receptors from clamped rats was enhanced despite removal of a $10 \mathrm{kD}$ fragment from the $\beta$ subunit C-terminus (Fig.6). Thus, the C-terminus does not play a regulatory role under our experimental conditions. If the differences in receptor autophosphorylation and kinase activity between fasted and clamped rats are indeed due to alterations in serine phosphorylation it would appear that the important site is not located in the C-terminus of the $\beta$ subunit.

The measurements of autophosphorylation and kinase activity were carried out in partially purified glycoprotein mixtures which contain the insulin receptor and phosphoprotein phosphatases. It is possible that the increased activity of the insulin receptor in tissues from insulin infused rats is due to inhibition of a phosphotyrosine phosphatase or to the activation of a phosphoserine phosphatase. Phosphatase activity in our studies was not specifically evaluated and thus, it is possible that the increased tyrosine phosphorylation which we report is not due to an activated insulin receptor.

The plasma insulin concentrations attained during the clamp (142 $\pm 9 \mathrm{mU} / \mathrm{l})$ are similar to peak levels after an oral glucose load [36] and thus, one might expect a similar activation of the receptor tyrosine kinase activity to occur in the fed state. Indeed activation of the tyrosine kinase activity of liver insulin receptors has been found after carbohydrate feeding of rats whilst a $72 \mathrm{~h}$ fast was associated with decreased enzyme activity [16]. The demonstration that the prevailing plasma insulin concentration results in stable changes in the insulin receptor tyrosine kinase might also account for the decreased kinase activity observed in the streptozotocin diabetic rat $[14,15]$, a model characterised by insulin deficiency.

In summary, our studies suggest that the prevailing insulin concentration in vivo affects the tyrosine kinase activity of liver and muscle insulin receptors measured in vitro. The regulatory mechanism involved is unknown. It would seem prudent that comparisons of receptor tyrosine kinase activity in tissues from insulin resistant and normal subjects are made after similar in vivo exposure of tissues to insulin.

Acknowledgements. We thank Miss A. Skvorak for excellent technical assistance. The study was supported by NIH Grants DK 35292 (PAH), DK 38712 (MFW), DK 33201 (CRK), a Diabetes and Endocrinology Research Centre Grant DK 36836 and the Greenwall Foundation. Dr. Y.Kruszynska was the recipient of a Wellcome Trust Travel Award. 


\section{References}

1. Kasuga M, Karlsson FA, Kahn CR (1982) Insulin stimulates the phosphorylation of the $95000-D a l t o n$ subunit of its own receptor. Science 215: 185-187

2. Nemenoff RA, Kwok YC, Shulman GI, Blackshear PJ, Osathanondh R, Avruch J (1984) Insulin-stimulated tyrosine protein kinase. Characterisation and relation to the insulin receptor. J Biol Chem 259: 5058-5065

3. White MF, Stegmann EW, Dull TJ, Ullrich A, Kahn CR (1987) Characterisation of an endogenous substrate of the insulin receptor in cultured cells. J Biol Chem 262: 9769-9777

4. White MF, Takayama S, Kahn CR (1985) Differences in the sites of phosphorylation of the insulin receptor in vivo and in vitro. J Biol Chem 260: 9470-9478

5. Ellis L, Clauser E, Morgan DO, Edery M, Roth RA, Rutter WJ (1986) Replacement of insulin receptor tyrosine residues 1162 and 1163 compromises insulin-stimulated kinase activity and uptake of 2-deoxyglucose. Cell 45: 721-732

6. Ebina Y, Araki E, Taira M, Shimada F, Mori M, Craik C, Siddle K, Pierce S, Roth RA, Rutter WJ (1987) Replacement of lysine residue 1030 in the putative ATP-binding region of the insulin receptor abolishes insulin - and antibody-stimulated glucose uptake and receptor kinase activity. Proc Natl Acad Sci USA 84: $704-708$

7. Morgan DO, Roth RA (1987) Acute insulin action requires insulin receptor kinase activity. Introduction of an inhibitory monoclonal antibody into mammalian cells blocks the rapid effects of insulin. Proc Natl Acad Sci 84: 41-45

8. Goldfine ID (1987) The insulin receptor: molecular biology and transmembrane signalling. Endocrinol Rev 8: 235-255

9. Kahn CR, Goldstein BJ (1989) Molecular defects in insulin action. Science 245: 13

10. Friedenberg GR, Henry RR, Klein HH, Reichard DR, Olefsky JM (1987) Decreased kinase activity of insulin receptors from adipocytes of non-insulin dependent diabetic subjects. J Clin Invest 79:240-250

11. Caro J, Ittopp O, Poris WJ, Meelhem D, Flickinger EG, Thomas F, Jenquin M, Silverman JF, Khanzanie PG, Sinha MK (1986) Studies of the mechanisms of insulin resistance in the liver from humans with non-insulin dependent diabetes. $\mathrm{J}$ Clin Invest 78 : 249-258

12. Arner P, Pollare T, Lithell H, Livingston JN (1987) Defective insulin receptor tyrosine kinase in human skeletal muscle in obesity and Type 2 (non-insulin-dependent) diabetes mellitus. Diabetologia 30: 437-440

13. Obermaier-Kusser B, White MF, Pongratz DE, Su Z, Ermel B, Muhlbacher C, Haring HU (1989) A defective intramolecular autoactivation cascade may cause the reduced kinase activity of the skeletal muscle insulin receptor from patients with non-insulin-dependent diabetes mellitus. J Biol Chem 264: 9497-9504

14. Burant CF, Treutelaar MK, Buse MG (1986) Diabetes induced functional and structural changes in insulin receptors from rat skeletal muscle. J Clin Invest 78: 260-270

15. Okamoto M, White MF, Maron R, Kahn CR (1.986) Autophosphorylation and kinase activity of insulin receptor in diabetic rats. Am J Physiol 251: E542-E550

16. Freidenberg GR, Klein HH, Cordera R, Olefsky JM (1985) Insulin receptor kinase activity in rat liver: regulation by fasting and high carbohydrate feeding. J Biol Chem 260: 12444-12453

17. Takata Y, Sasaoka T, Iwasaki M, Shigeta Y (1988) Alteration of the insulin-receptor kinase activity by high fat feeding. Diabetes 37: 1397-1404

18. White MF, Shoelson SE, Keutmann H, Kahn CR (1988) A cascade of tyrosine autophosphorylation in the $\beta$ subunit activates the phosphotransferase of the insulin receptor. J Biol Chem 263: 2969-2980

19. Tavare JM, Denton RM (1988) Studies on the autophosphorylation of the insulin receptor from human placenta. Analysis of sites phosphorylated by two-dimensional peptide mapping. Biochem J 252: 607-615

20. Tornquist HE, Avruch J (1988) Relationship of site-specific $\beta$ subunit tyrosine autophosphorylation to insulin activation of the insulin receptor (tyrosine protein kinase activity). J Biol Chem 263: 4593-4601

21. Shoelson SE, White MF, Kahn CR (1988) Tryptic activation of the insulin receptor. Proteolytic truncation of the $\alpha$-subunit releases the $\beta$-subunit from inhibitory control. J Biol Chem 263: $4852-4960$

22. Takayama S, White MF, Kahn CR (1988) Phorbol ester-induced serine phosphorylation of the insulin receptor decreases its tyrosine kinase activity. J Biol Chem 263:3440-3447

23. Tornquist HE, Gunsalus JR, Nemenoff RA, Frackelton AR, Pierce MW, Avruch J (1988) Identification of the insulin receptor tyrosine residues undergoing insulin-stimulated phosphorylation in intact rat hepatoma cells. J Biol Chem 263: 350-359

24. Kraegen EW, James DE, Bennett SP, Chisholm DJ (1983) In vivo insulin sensitivity in the rat determined by euglycaemic clamp. Am J Physiol 245: E1-E7

25. Bradford MM (1976) A rapid and sensitive method for the quantitation of microgram quantities of protein utilising the principle of protein-dye binding. Anal Biochem 72: 246-254

26. Desbuquois B, Aurbach GD (1971) Use of polyethylene glycol to separate free and antibody-bound peptide hormones in radioimmunoassays. J Clin Endocrinol 33: 732-738

27. Pang DT, Sharma BR, Shafer JR (1985) Purification of the catalytically active phosphorylated form of insulin receptor kinase by affinity chromatography with $\mathrm{O}$-phosphotyrosyl-binding antibodies. Arch Biochem Biophys 242: 176-186

28. Goren HJ, White MF, Kahn CR (1987) Separate domains of the insulin receptor contain sites of autophosphorylation and tyrosine kinase activity. Biochemistry $26: 2374-2382$

29. Heding LG (1972) Determination of total serum insulin (IRI) in insulin-treated diabetic patients. Diabetologia 8:260-266

30. Reddy SSK, Kahn CR (1988) Insulin resistance: a look at the role of insulin receptor kinase. Diabetic Med 5: 621-629

31. Merion M, Sly WS (1983) The role of intermediate vesicles in the adsorptive endocytosis and transport of ligand to lysosomes by human fibroblasts. J Cell Biol 96: 644-650

32. Posner BI, Khan MN, Bergeron JJM (1987) Internalisation of insulin and its receptor: role in signaling. In: Raizada MK, Phillips MR, Le Roith DD (eds). Insulin, insulin-like growth factors and their receptors in the central nervous system. Plenum Press, New York London, pp 1-10

33. Ballotti R, Kowalski A, White MF, Le Marchand-Brustel Y, Van Obberghen E (1987) Insulin stimulated tyrosine phosphorylation of its receptor $\beta$-subunit in intact rat hepatocytes. Biochem $J$ 241:99-104

34. Pang DT, Sharma B, Shafer JA, White MF, Kahn CR (1985) Predominance of tyrosine phosphorylation of insulin receptors during the insulin response of intact cells to insulin. $J$ Biol Chem 260: 7131-7136

35. Takayama S, White MF, Lauris V, Kahn CR (1984) Phorbol esters modulate insulin receptor phosphorylation and insulin action in cultured hepatoma cells. Proc Natl Acad Sci USA 81: $7797-7801$

36. Kruszynska YT, Home PD, Alberti KGMM (1985) Comparison of portal and peripheral insulin delivery on carbohydrate metabolism in streptozotocin diabetic rats. Diabetologia 28: 167-171

Received: 27 June 1989

and in revised form: 9 October 1989

Dr. Y. Kruszynska

Academic Department of Medicine

Royal Free Hospital

Pond Street

London NW32QG

UK 